報 Soc. Cosmet. Chem. Jpn.

$27(3) \quad 424-431 \quad(1993)$

\title{
毛髪の物性およびタンパク緸造に対する紫外線の影響や1
}

\author{
金高節子 $\dagger^{2}$ ，冨沢庫司朗 $\dagger^{2}$ ，伊与博美 $\dagger^{2}$ ，中村良治 $\dagger^{3}$ \\ 日華化学株式会社 デミ毛髮科学研究所中2 \\ 福井大学 工学部生物化学工学科 ${ }^{3}$
}

\section{The Effects of UV Radiation on Human Hair Concerning Physical Properties and Fine Structure of Protein}

\author{
Setsuko Kanetaka $\uparrow^{2}$, Koshiro Tomizawa $\uparrow^{2}$, \\ Hiromi Iyo $\dagger^{2}$ and Yoshiharu Nakamura $\dagger^{3}$ \\ NICCA Chemical Co. Ltd. †े \\ Fukui University $\uparrow^{3}$
}

\begin{abstract}
The effects of UV radiation on human hair were examined concerning physical properties and fine structure of internal protein. The breaking strength of sample hair decreased from $152 \mathrm{~g}$ to $138 \mathrm{~g}$, depending on UV irradiation period for 0 to 55 hours. Water content decreased from 10 to $7 \%$ at first 10 hrs exposure and became almost constant after that. The significant damage brought by UV exposure was observed on the cuticle surface and the internal section of sample hair by SEM. M.W. and amino acid composition of extracts eluted by two kinds of solvent were examined. With the increase of UV irradiation period, M.W. seemed to decrease and cysteinic acid increased significantly. X-Ray diffraction analysis suggested that UV irradiation and elution process brought on sample hair affect not only hair surface but also the structure of internal keratinous protein. It may be concluded that the effects on physical properties of hair by UV irradiation are attributed to both the damage of cuticle and the degradation of internal prorein.
\end{abstract}

\section{1. 緒言}

毛髪は皮膚と同様に紫外線によって大なり小な り損傷することは，既に知られていることである が，このことはマリンスポーツや長時間の戸外労 働に携わる人にとっては特に深刻な問題である。 しかしながら，毛髪 ${ }^{12}$ (2) に対しては皮膚3) 5) に対

†1 第17回 IFSCC 横浜大会（'92年10月）で口頭発表

$\dagger^{2}$ T 910 福井市文京4-23-1；4-23-1 Bunkyou， Fukui-city, 910 Japan

$\dagger^{3}$ T910 福井市文京 3-9-1; 3-9-1 Bunkyou, Fukuicity, 910 Japan
するような詳細な研究は，殆ど行われておらず， 損傷の機構に関しては不明な部分が多い。

そこで本報では，紫外線によって稂が髪摥し ていく機構を, 破断強度, 水分含量等の毛髴物性 値の変化，走査型電子顕微鏡による毛髮表面観察 执よび内部タンパク構造の変化の追跡等を通じ て，明らかにしていくことを目的として研究を行 ったので，その結果について報告する。

\section{2. 実験}

\section{1 試料及び試薬}

\section{1 .1 毛髮試料}


中国人毛（中国上り輸入，年齢，性 別履 歴 不 詳）及び日本人バージン毛（15歳女子頭髮）

\section{1 .2 試 薬}

チオグリコール酸アンモニウム恃佐々木化学製 の市販原料を，末た，2-メルカプトエタノール， 尿酸, 塩酸及び $4 \mathrm{~N}$-メタンスルフォン酸は半井テ スク製の特級試薬を用いた。その他，電気泳動用 試薬, アミノ酸分析用試薬は和光純薬製及び半井 テスク製特級試薬を用いた。

\section{2 実験方法}

毛髪サンプルに対する紫外線照射は，東芝製 $400 \mathrm{~W}$ 水銀紫外線照射ランプ ( $\mathrm{H}-400 \mathrm{P}$ 型) を用 いた。その強度は, $50 \mathrm{~cm}$ 離孔て $1.2 \mathrm{~mW} / \mathrm{cm}^{2}$ で あり，UVAを選択する場合には，320nm 以下を カットする硬質ガラスフィルターを使用した。ぬ た，毛髪の溶出処理は $0.5 \mathrm{M} 2$ 2-メルカプトエタ， ール $/ 10 \mathrm{M}$ 尿素で行った。

照射した毛髪サンプルについて，強伸度測定， 含水量の測定, 走査型電顕による表面拉よび断面 り観察及びX線回折測定を行った。これら物性值 つ測定には上記日本人バージン毛を用いた。

強伸度の測定は, FUDOH レオィター NRM$20107 \mathrm{~J}$ を用い 70 80 $\mu \mathrm{m}$ の毛髮30本について行 い, その平均值を求めた。

含水量の測定は，照射後毛髮を 1 時間 $25^{\circ} \mathrm{C}$, 20\%RH の恒温恒湿に保った後, HIRANUMA エヴァポレーターを用いカールフィッシャー法に より 2 回測定を行い，その平均值をとった。

X線回折パターンの測定は20 30本束站た毛髪 について, 東芝X線発生装置 $\mathrm{XC} 40 \mathrm{H}$ 型 $(35 \mathrm{kV}$, $10 \mathrm{~mA}, \mathrm{Ni}$ フィルター濾過, $1.54 \AA$ の $\mathrm{CuK} \alpha$ 線) を用い広角で 6 時間露光で行った。

強度測定は理学電気装置 $2020 \mathrm{~A}$ 型 $(35 \mathrm{kV}$,

$15 \mathrm{~mA}, \mathrm{Ni}$ フィルター濾過 $\mathrm{CuK} \alpha$ 線, 散乱スリ ット：0.5申, 受光スリット: $1 \times 1 \mathrm{~mm})$ を用い, 散乱角 $1^{\circ}$ から $35^{\circ}$ の範囲で行った。

溶出タンパクの分析には中国人毛髮を用いた。 $10 \mathrm{~g}$ の細断した中国人毛の照射サンプルは振湓恒 温水槽で $40^{\circ} \mathrm{C}, 1$ 時間， 2 種類の溶出液 (0.5 $\mathrm{M}$ チオグリュール酸/10M 尿素又ほ $0.5 \mathrm{M} \mathrm{2-人}$ ルカプトエタノール $/ 10 \mathrm{M}$ 尿素） $100 \mathrm{ml}$ を用い
て溶出操作を行った。溶出後, 毛髮を濾別し, 濾 液と洗液を合わせ，分画分子量 3500 の透析チュ 一ブにいれ，蒸留水を流しながら 2 日間透析を行 った後，溶出液は， $-110^{\circ} \mathrm{C}$ で約 2 日間，完全凍 結乾燥を行った後, 精科し, 溶出率を算出した。 溶出タンパクの分子量は, SDS ポリアクリルアミ ドゲル電気泳動により標準タンパクをマーカーと して測定した6)。溶出タンパクのアミノ酸組成分 析は $4 \mathrm{~N}$-メタンスルフォン酸中で， $110^{\circ} \mathrm{C}, 24$ 時 間加水分解を行った後, $1 \mathrm{~N}-\mathrm{NaOH}$ で中和, 島津 LC9A 型アミノアナライザーにより行った7)。

\section{3. 結果}

\section{1 紫外線照射時間と破断強度の関係}

Fig.-1に，上述の条件で測定した日本人バー ジン毛の全波長 UV あるいは UVA 照射時間と 破断強度の関係表す。

破断強度は全波長 UV 呿よび UVA のいずれ についても照射時間に対してほぼ直線的に減少し ている。56時間照射で，約10\%の強度の減少が見 られた（T検定により危険率 $5 \%$ で有意差㐫りと 判定された)。

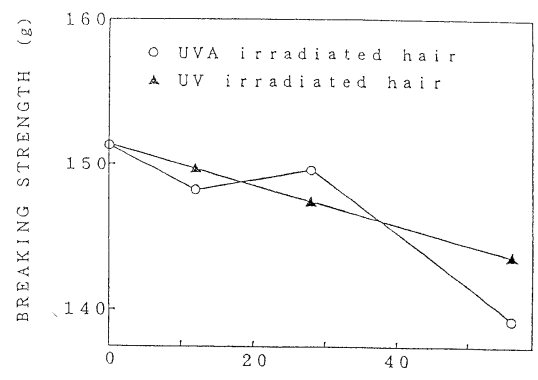

UV. UVA IRRADIATION TIME (hr)

Fig.-1 Breaking strength of UV or UVA irradiated hair samples.

\section{2 紫外線照射と含水量の関係}

Fig.-2 は日本人バージン毛サンプルKUV あ るいはUVA 照射後、上述の条件で測定した含水 量と照射時間の相関を表したグラフで岁る。

最初の10時間の照射で含水量は約半分に下が 


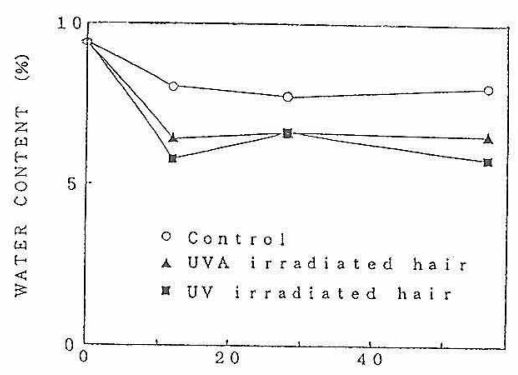

UV, UVA IRRADIATION TIME (hr)

Fig.-2 The relations between water content and UV or UVA irradiation time.
り、その後ほぼ一定に保たれる。UV およびUVA のいずれについてもこの傾向は同じで（UVA よ りUV の方がやや大), 毛髰内の自由水は照射に より蒸発しやすいが, タンパに結合している構 造水は比較的逃げにくいことを示していると思わ れる。ただ，UV 照射に伴ら温度上昇による寄 与を調ベな結果を図中コントロールに示した。約 $30 \%$ 寄与が見られた。

\section{3 照射毛髪の表面および断面の状態}

Fig.-3は走查型電子顕微鏡による56時間 UV 照射日本人バージン毛の表面桼よび断面の写真で 市る。

照射後のキューティクルは剥離あるい性融解し ているように見劣る。断面の写真から毛鬞は照射

unirradiated hair
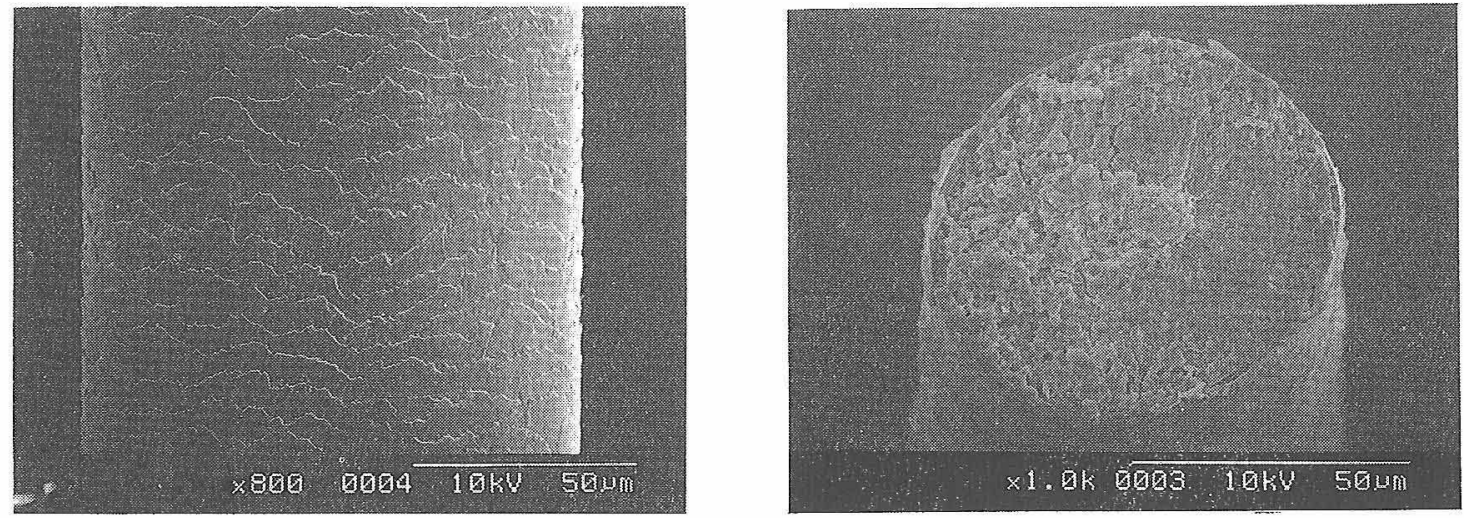

irradiated hair

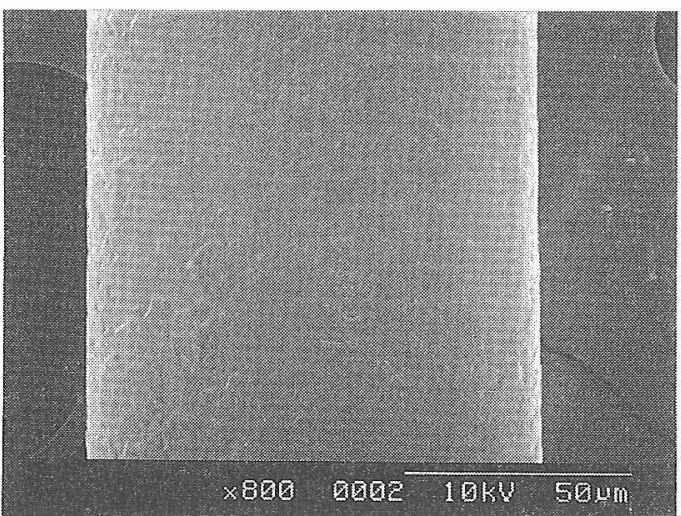

a) hair surface

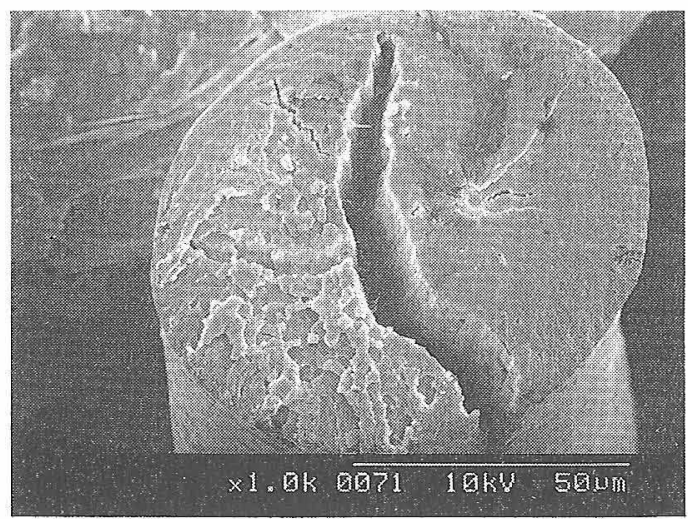

b) cross section

Fig.-3 SEM photographies of unirradiated and irradiated hair. 
により，間充タンパクが水分を失い，組織の劣化 が起こり，裂け易くなったと説明できると思われ

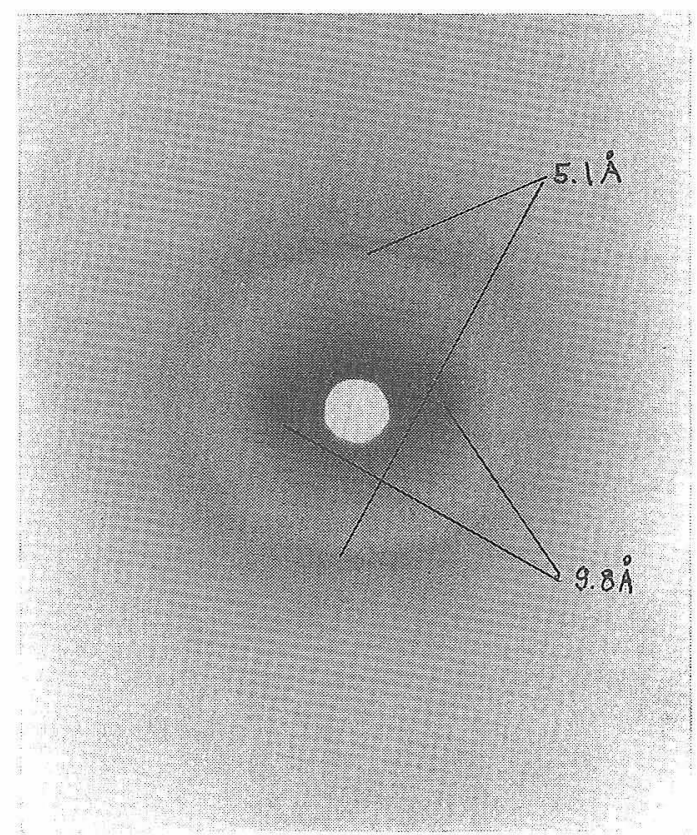

blank hair

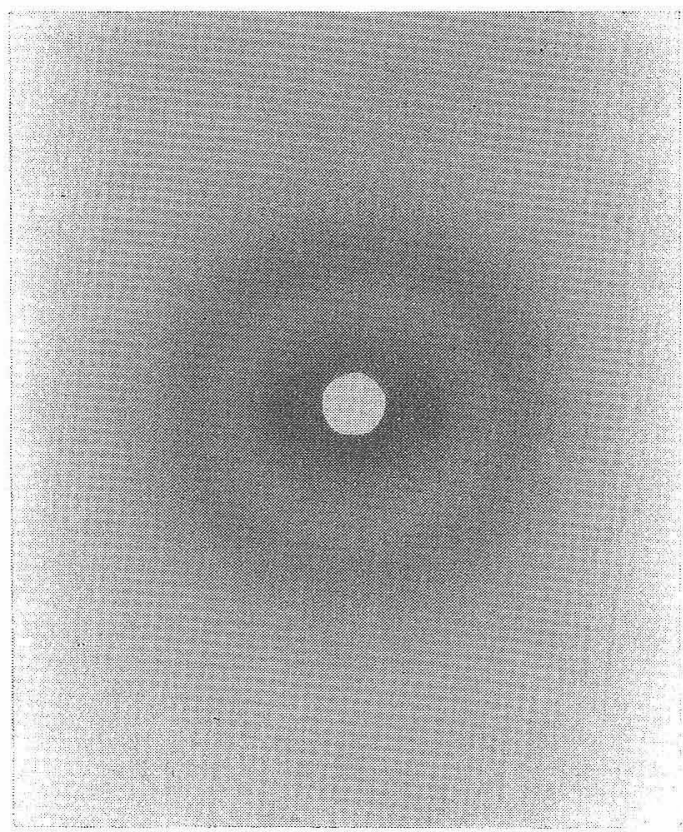

$30 \%$ extended hair
る。サンプル毛は，照射によって赤色化したが， 今回カラーコンピューターにより定量的に表わす

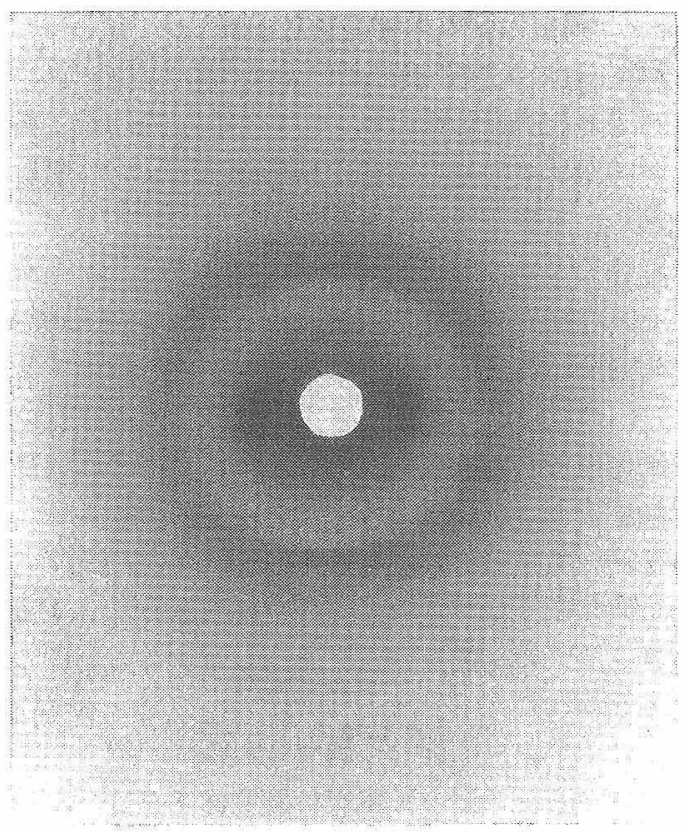

UV irradiated hair

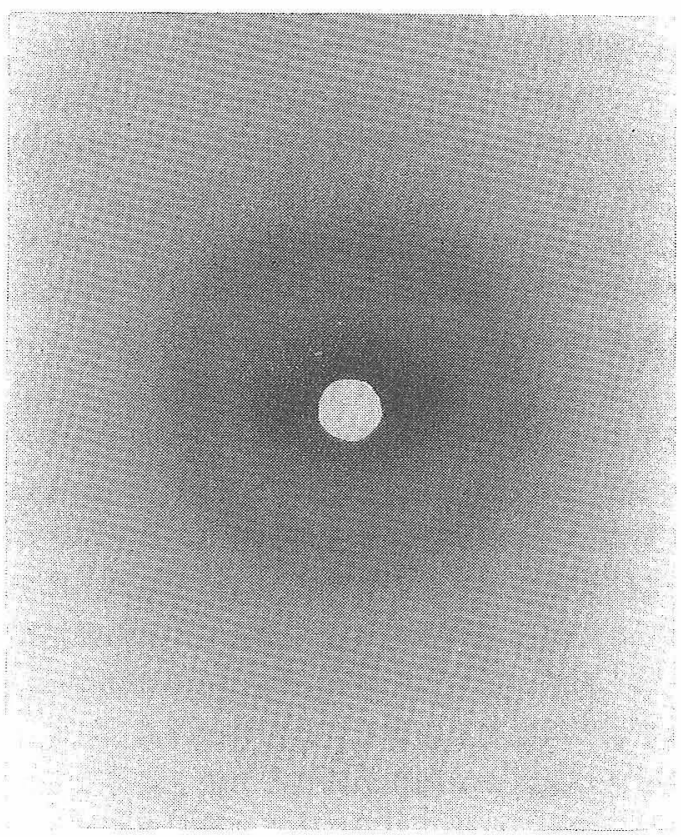

UV irradiated hair after $30 \%$ extending

Fig. -4 X-ray diffraction patterns.

J. Soc. Cosmet. Chem. Japan. Vol.27, No.1 1993 


\section{ことはできなかった。}

一方 UVA 学同時間照射した場合, 電顕観察の 結果から漂とんぞ損傷は見られなかった。

\section{4 照射毛髮の $\mathbf{X}$ 線回折}

Tig.-4のX線回折パターンは日本人毛のブラ ンク毛と 56 時間 UV 照射したそれとの比較，和 上び30\%延伸毛之，30\% 延伸後56時間 UV 照射 を行った毛髪との此較である。

延伸していない毛髮の場合, 典型的な $\alpha$ てい ックスのパターン，すなわちへリックス鎖間距離 に相当する $9.8 \AA$ のバンドと，ピッチに相当する $5.1 \AA$ のシャープなアークが鮮明に認められる。 30\%延伸したものでは， $5.1 \AA$ のアークは認め られず $\beta$ 一構造への移行を示している8,,9)。延伸, 無延伸いずれの場合も, UV 照射により, 全体に 回折像はぼやけてくる。この事は, UVによる毛 髮タンパクの結晶性の低下を示しているとい方る か子知れない。

この結果を更に詳しく調べるために, 種々の条 件で処理した毛髪のX線回折強度測定を $1^{\circ}$ から $35^{\circ}$ の範囲で赤道方向之子午線方向について行っ た( Fig. -5$)$ 。

赤道力向の $9.8 \AA$ のバンドは UV 照射のみに よっては強度が变化しないが, 照射後溶出操作や 延伸操作を行うことにより，このバンドの強度が 減少してくるのが判る。子午線方向の強度測定か

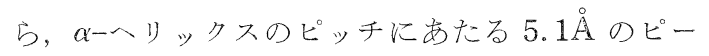
クが UV 照射のみでは変化しないが，照射後溶 出処理を行ったものではこのバンドは低位にシフ トし， $\beta$-シート構造を示すと思われる回折ピーク が子午線方向 $4.5 \AA$ 付近に認められるようになっ た。溶出操作を加えることにより，更にこの傾向 は強まって打り，30\%延伸のパターンに近づいて くる。更に, 延伸と溶出を組又合わせることによ り,この傾向は一層強まってくる。これらの結果 から，UV 照射のみではミクロフィブリルの $\alpha-$ ヘリックスは直接影響を受けないが，低結晶性タ ンパクのンスチン結合が開裂して動き易くなり, 還元剂液を用いる溶出操作による引張り力が加わ ることにより，一部， $\beta$-構造への再配列が行われ たと推察される。
(1) equatorial direction

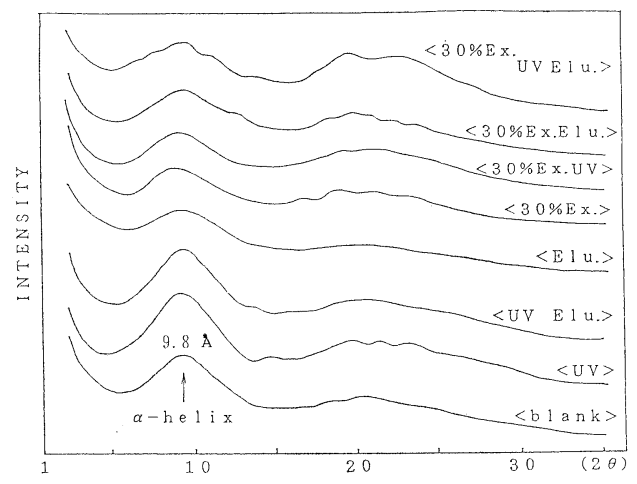

(2) meridional direction

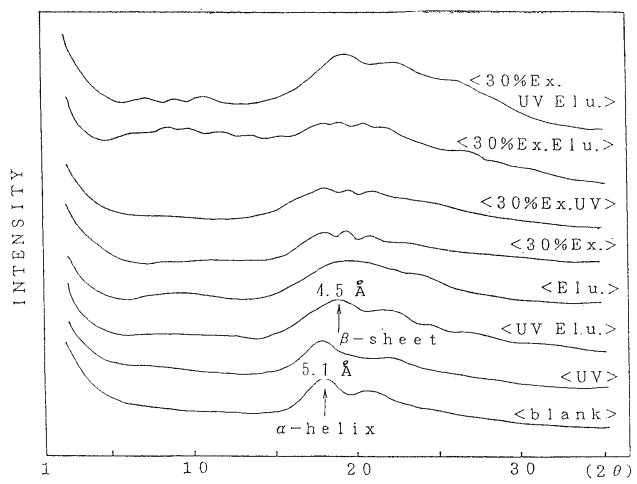

Fig. -5 Densitometric analysis of various patterns.

[blank]: blank hair, [UV]: UV irradiated hair, [UV, Elu] : hair eluted by 2-mercha pto ethanol/10M Urea after UV irradiation, [Elu.] : hair eluted by above sol., [30\% Ex.]: 30\% extended hair, [30\% Ex. UV] : UV irradiated hair after $30 \%$ extention, [30\% Ex. Elu.]: hair eluted by above sol. after $30 \%$ extention, [30\% Ex. UV Elu.]: hair $30 \%$ extended, then UV irradiated and eluted by above sol.

\section{5 溶出タンパクの性状について}

UV 特よびUVA 照射を行った中国人毛からの 2-メルカプトエタノール/10M尿素による溶出物 は, ケラチン性特よび非ヶラチン性タンパク, メ ラニン分解物, 脂質および痕跡量のミネラルから 
なっていることが確かめられた。

Fig.-6 飞示すSDSポリアクリルアミドゲル電 気泳動によって求められた溶出タンパクの分子量 は, 5,000から 60,000の範囲に分布している。更 に分子量はUV 照射時間が長くなるほど徐々に低 くなっているのが認められる。この低い部分は, UVによるジスルフィド結合の開裂により劣化し たタンパクに相当するものと思われる。

これらの溶出物の溶出率と照射時間との関係を 耻ig: -7 亿示す。

照射の初期段階（28時間）で一旦上昇し，更に

(a) UV
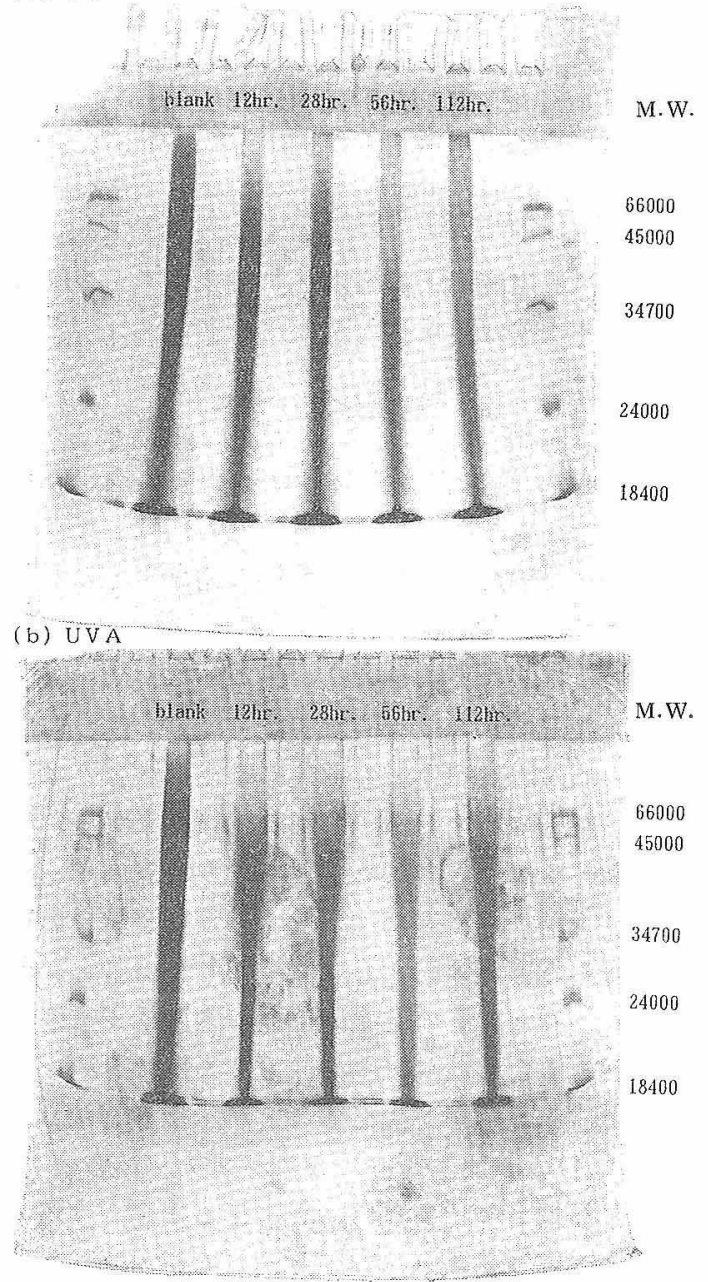

Fig.-6 SDS polyacrylamide gel electrophoresis of eluted products.

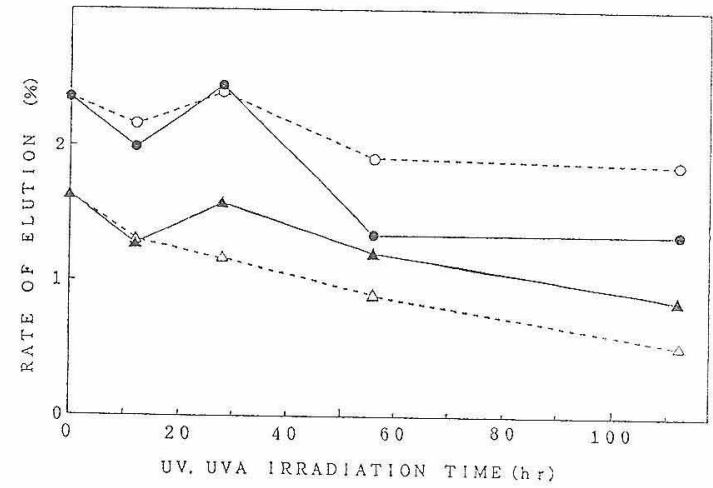

Fig.-7 The rate of elution depending on UV or UVA irradiation time.

- - UV exposed and eluted by 0.5 M 2-merchaptoethanol in $10 \mathrm{M}$ urea

- $\mathbf{A}$ - UV exposed and eluted by 0.5 $\mathrm{M}$ ammonium thioglycolate in $10 \mathrm{M}$ urea

- - - - UVA exposed and elutied by $0.5 \mathrm{M}$ 2-merchaptoethanol in $10 \mathrm{M}$ urea

$-\cdots--$ UVA exposed and eluted by $0.5 \mathrm{M}$ ammonium thioglycolate in $10 \mathrm{M}$ urea

過剩の照射で緩やかではよるが減少する傾问を示 した。この傾向は, 照射の初期段階ではタラチン タンパクはジスルフィド結合の開裂により低分子 量化し溶出し易くなるが，過剩な照射を行らこと により架橋結合が逆に促進され溶出儿難い状態に なるるのと䠸觉らる。

2-メルカプトエタノール/10M 尿素による, UV るいは UVA の 56 時間照射の毛髮溶出タ

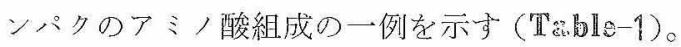
ぬた，特徴的なアミ，酸についての照射時間之の 㥵関を面ig.-8 に示す。

UV 照射時間と共にンステイン酸は明らかに赠 大しているが，チロシン和よびトリプトファンは 徐々に減少している。この結果は, 反応性に富も ジスルフィド結合がUVエネルギーにより酸化的 に開裂した後，活性酸素により更に酸化が進みシ ステイン酸が生成されたと説明できる。 
Table-1 Amino acid composition of extracts from 56 hrs irradiated hair by 2merchaptoethanol/10M urea

\begin{tabular}{lcc}
\hline Amino acid & $\begin{array}{c}\text { UV 56hr. } \\
\text { mol\% }\end{array}$ & $\begin{array}{l}\text { UVA } 56 \mathrm{hr} . \\
\text { mol\% }\end{array}$ \\
\hline $\mathrm{CySO}_{3} \mathrm{H}$ & 3.02 & 1.29 \\
Asp & 6.01 & 4.56 \\
Thr & 6.92 & 11.77 \\
Ser & 16.90 & 17.90 \\
Glu & 12.21 & 10.92 \\
Pro & 4.47 & 9.77 \\
Gly & 10.86 & 10.37 \\
Ala & 7.14 & 4.35 \\
Cys (half) & 7.00 & 5.87 \\
Val & 0.48 & 0.29 \\
Met & 2.21 & 2.36 \\
Ile & 6.29 & 5.75 \\
Leu & 1.92 & 2.93 \\
Tyr & 2.26 & 2.45 \\
Phe & 0.78 & 1.00 \\
His & trace & 0.38 \\
Trp & 1.83 & 0.91 \\
Lys & 6.88 & 7.14 \\
Arg & & \\
\hline & &
\end{tabular}

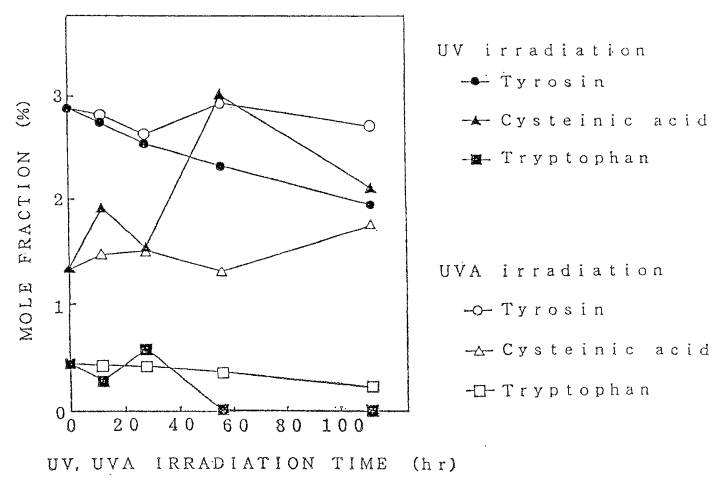

Fig.-8 Change of composition of several amino acids with irradiation time.

他方，チロシンとトリプトファンはUVエネ ルギーを選択的に吸収して構造変化を起こすとい われて拈り，本研究の結果でもとのことが示され たと言える。事実, 長時間照射でその近くに同定 不明のピークが明睹に見られた（Fig.-9）。また，

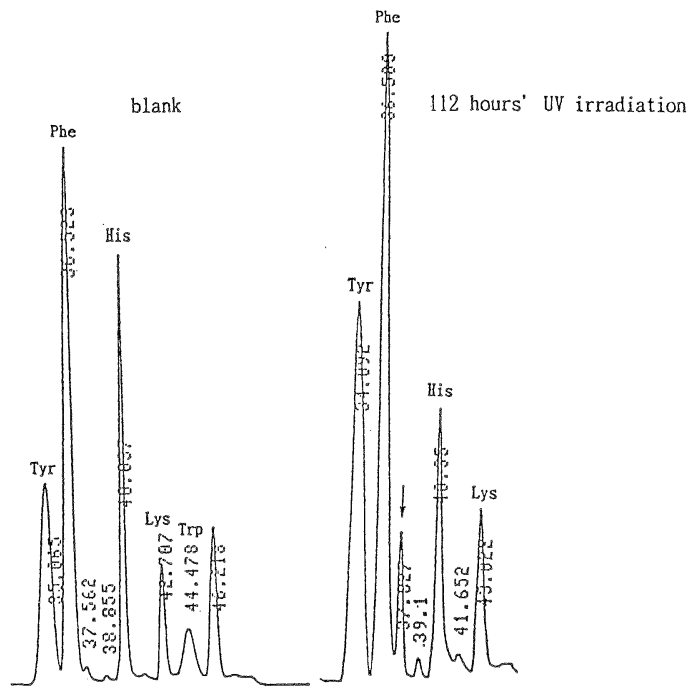

Fig.-9 Typical analysis chart of amino acids composition.

二種類の溶出液による溶出タンパクのアミノ酸組 成の間には差は見られなかった。

\section{4. 結論および考察}

毛髪の UV による損傷に関しては，既に言わ れてきたことであるが，損傷の内容に関しては報 告が少なく僅かに毛髪の赤色化に関するものが見 られるだけである。

今回の私共の実験結果は，使用したUVランプ の下での毛髪サンプルに対するものであり，これ が直ちに太陽光の下での毛髪に与える影響とは言 完ないかも知れないが，今回の実験結果から，毛 髪は紫外線に暴露されることにより，表面キュ一 ティクルが損傷するだけでなく内部構造なで影響 を受けることが傾向としては起こりらることが明 らかにされた。その結果, 毛髪の強度低下や水分 量の減少によるパサツキや枝毛, またメラニン分 解による赤毛などが生じることが示唆された。

更にUVエネルギーによるシスチン結合の開 裂およびシステイン酸の増大による損傷，またと の上にパーマや染毛などの薬剂処理が加わるとタ ンパク溶出が促進され, 更に内部タンパク構造ま で変化を受け，これが更に物性変化を促進する可 
能性が示された。しかしながら, 毛髮の複雑な構 造や個体差などのゆ光に今回の実験から内部構造 に及ぼす影響をすべて明らかにすることはできな かった。また，毛髪に含まれる脂質に対する影響 については，今回手をつけることができず今後の 課題として残された。

\section{引用文献}

1) 龍田真伸, 植村雅明, 鳥居健二, 松岡昌弘, 粧技 誌, $21 ， 43 \sim 49$ (1987)

2) L. J. Wolfram and L. Albrecht, J. Soc. Cosmet. Chem. 38, 179 191 (1987)

3) 土屋 徹, 堀井和泉, 中山靖久, 粧技誌, 22,10 $\sim 14$ (1988)

4) 福田 實, 長沼雅子, 岩井美枝子, 中山靖久, 粧 技誌，22，5９（1988）

5) 岡田富雄, 他, 粧技誌, 19, 105 110 (1985)

6) Y. Nakamura, K. Kosaka, M. Tada, K. Hirota and S. Kunugi, Proc. 7th. Int. Wool Text. Res. Conf. Tokyo, 1, 171 180 (1980)

7 ) 金高節子, 宮田勝保, 中村良治, 粧技誌, 24, 5 11 (1990)

8) Fraser and Macrae "Conformation in Fibrous Protein” p. 469 477 (1977)

9) J. C. Garson, J. Doucet, G. Isocaris and J. L. Lévěque, J. Soc. Cosmet. Chem., 41, 347 $\sim 358$ (1990)

（1993年 4 月20日受理） 